\title{
Peran Teori Kontingen Sebagai Variabel Moderasi dan Efek Mediasi Terhadap Kinerja Perusahaan
}

\section{Nama : Adra Elviona Regina}

NRP : 130119056

\section{Mata Kuliah : Simulasi Mikro Ekonomi Dalam Bisnis}

$\mathbf{K P}: \mathbf{A}$

Teori kontingensi ini merupakan teori perilaku yang menyatakan bahwa keadaan manajemen atau organisasi bergantung pada situasi internal dan eksternal suatu perusahaan (Ganescu, 2012). Teori kontingensi juga merupakan teori yang mampu untuk memahami keseimbangan serta keterkaitan yang ada pada lingkungan bisnis internal maupun eksternal (Tangpong, Hung, \& Li, 2019). Tertulis pada jurnal Pratono 2016 ini menganalisis adanya suatu penggunaan teori kontingensi dengan cara menerapkan Technology Turbulance (TT) yang membuktikan adanya pengaruh yang diberikan dengan moderating variable (Pratono A., 2016).

Dalam hal ini Technology Turbulance (TT) merupakan suatu variable independen atau sebagai variable yang dapat mempengaruhi. TT yang termasuk dalam independen variable ini salah satu contohnya ialah pengaruh terhadap strategic orientation. Tidak hanya variable independen saja yang dapat mempengaruhi tetapi juga ada variable dependen yang dipengaruhi yaitu terhadap suatu kinerja perusahaan atau firm performances. Dari sini dapat ditunjukkan bahwa TT memiliki peran yang bisa dibilang sangat penting dan signifikan pada orientasi pasar (Pratono A. , 2016). Hal yang dipengaruhi oleh TT ini dapat dilihat pada grafik yang dimana menunjukkan suatu keadaan risk taking behavior apabila grafik tersebut menunjukan high TT ini akan berpengaruh negative pada moderating variable. Tidak hanya itu, keadaan TT ini dapat dilihat pada grafik yang dimana menunjukkan suatu keadaan risk taking behavior apabila grafik tersebut menunjukan low TT ini akan berpengaruh positif pada moderating variable (Pratono A. , Does firm performance increase with risk-taking behavior under information technological turbulence? Empirical evidence from Indonesian SMEs., 2018). 
Selanjutnya terdapat perbandingan analisis yang digunakan yaitu adanya suatu peran penting yang dilakukan oleh analisis big data guna dalam proses pengambilan keputusan dan operasi perusahaan. Hal ini memiliki hubungan yang terkait antara CSR (Corporate Social Respinsibility) dan GSCM (Green Supply Chain Management) dengan analisis big data sebagai moderating variable yang digunakan. Sehingga dari sini dapat disimpulkan bahwa tingkat CSR yang ada dalam lingkungan internal dan eksternal serta ini akan memberikan pengaruh positif terhadap GSCM. Pengaruh positif inilah yang mampu memberikan dampak yang baik bagi kemajuan kinerja perusahaan atau Firm Performances (Wang, Zhang, \& Zhang, 2020). Selain itu terdapat juga perbandingan analisis yang digunakan yaitu adanya suatu peran penting yang dilakukan oleh analisis karakteristik pelanggan guna dalam proses pengambilan keputusan dan operasi perusahaan. Dalam hal ini secara tak langsung menjadi salah satu hal signifikan karena dalam artikel ini menyatakan bahwa karakteristik pelanggan yang bermacam seperti stabilitas, hak pelanggan dll akan memberi pengaruh yang postif dan dalam hal ini suatu kinerja perusahaan atau Firm Performances akan meningkat (Shi, Conghui, \& Liu, 2020)

Mediating Effect atau yang biasa disebut efek mediasi ini merupakan suatu mediasi dimana di dalamnya terdapat variable - variable dependen yang dimana variable ini dipengaruhi dan bergantung pada variabel lainnya.Peran dari efek mediasi sendiri ini adalah mengembangkan model persamaan struktural untuk menjelaskan hubungan kompleks antara jejaring sosial dan kinerja perusahaan dengan memperkenalkan peran mediasi dari kepercayaan, kemampuan menjual dan kemampuan harga (Pratono A. , 2018). Selain itu mediasi efek ini terdapat variable langsung yang dapat diuji yaitu kinerja Bank Finance dan perusahaan, hubungan dukungan pemerintah dan kinerja perusahaan dimediasi Oleh Keuangan Perilaku Bank Finance yang signifikan terhadap kinerja perusahaan. Selain efek langsung terhadap kinerja perusahaan, kompetensi pengusaha diduga memiliki efek mediasi hubungan antara keuangan bank dan kinerja perusahaan . Selain itu variable efek mediasi kompetensi pengusaha dan keuangan perilaku, efek keuangan bank dan keuangan perilaku terhadap kinerja perusahaan dihipotesiskan menjadi signifikan (Esubalewab \& Raghuramac, 2020).

Dalam artikel (1) menganalisis bahwa dalam Green Entrepreneurial Orientation (GEO) perusahaan harus dapat memandang hambatan yang ada sebagai pengertian jika mereka belum mengembangkan suatu orientasi kewirausahaan dan orientasi pasar yang disyaratkan. Maka dari 
itu terdapat mediating effect yang dimana ini akan memberikan dampak yang positif bagi orientasi kewirausahaan, orientasi pemasaran dan kinerja perusahaan dengan keunggulan yang kompetitif seiring dengan mengintropeksi kesalahan sebagai peluang belajar potensial. Hal ini lah yang dapat mengembangkan pembelajaran antar organisasi atau perusahaan untuk mengantisipasi, merespon, dan terus belajar dari mitra bisnis, serta mampu menunjukkan bahwa perusahaan nya siap-sedia jika menghadapi suatu masalah (Pratono, Darmasetiawan, \& Yudiarso, 2019).

Sedangkan di dalam artikel (2) menganalisis bahwa adanya hubungan positif antara jejaring sosial dan kinerja perusahaan. Dalam hal ini diperlukan adanya kepercayaan sebagai variabel mediasi yang kuat, yang memberikan penjelasan tentang proses penting dalam mengubah jaringan sosial menjadi Kinerja Perusahaan. Karena dalam jejaring sosial dapat dipercaya akan membantu perusahaan dalam mendapatkan manfaat dari kemampuan penetapan harga dan penjualan yang di tetapkan, sehingga ini akan memungkinkan mereka mencapai kinerja perusahaan dengan keunggulan yang kompetitif. Hasilnya dalam variabel - variable yang ada seperti jejaring sosial, kemampuan penetapan harga , serta kemampuan untuk menjual yang termasuk dalam variable mediasi ini akan lebih memberikan pengaruh yang besar dalam kemampuan kinerja perusahaan. (Pratono A. , 2018). 


\section{Bibliography}

Esubalewab, A. A., \& Raghuramac, A. (2020, May-August). The mediating effect of entrepreneurs' competency on the relationship between Bank finance and performance of micro, small, and medium enterprises (MSMEs). European Research on Management and Business Economics, 26(2), 87-95. doi:https://doi.org/10.1016/j.iedeen.2020.03.001

Ganescu, M. C. (2012). Assessing Corporate Social Performance from a Contingency Theory Perspective. Procedia Economics and Finance, 3, 999-1004. doi:https://doi.org/10.1016/S22125671(12)00264-X

Pratono, A. (2016). Strategic orientation and information technological turbulence: contingency perspective in SMEs. Business Process Management Journal, 22(2). doi:https://doi.org/10.1108/BPMJ-05-2015-0066

Pratono, A. (2018). Does firm performance increase with risk-taking behavior under information technological turbulence? Empirical evidence from Indonesian SMEs. Journal of Risk Finance, 19(4), 361-378. doi:https://doi.org/10.1108/JRF-10-2017-0170

Pratono, A. (2018). From social network to firm performance: "The mediating effect of trust, selling capability and pricing capability". Management Research Review, Vol.41 No.6,pp, 680-700.

Pratono, A., Darmasetiawan, N., \& Yudiarso, A. a. (2019). "Achieving sustainable competitive advantage through green entrepreneurial orientation and market orientation: The role of interorganizational learning". The Bottom Line, Vol. 32 No. 1, pp, 2-15.

Shi, J., Conghui, Y., \& Liu, X. (2020). Predicting firm stock returns with customer stock returns: Moderating effects of customer characteristics. Research in International Business and Finance, 54. doi:https://doi.org/10.1016/j.ribaf.2020.101280

Tangpong, C., Hung, K.-T., \& Li, J. (2019). Toward an agent-system contingency theory for behavioral supply chain and industrial marketing research. Industrial Marketing Management, 83, 134-147. doi:https://doi.org/10.1016/j.indmarman.2018.10.003

Wang, C., Zhang, Q., \& Zhang, W. (2020, September 15). Corporate social responsibility, Green supply chain management and firm performance: The moderating role of big-data analytics capability. Research in Transportation Business \& Management. doi:https://doi.org/10.1016/j.ribaf.2020.101280 